\title{
THE EFFECTS OF MICROWAVE APPLICATION ON THE PHYSICOCHEMICAL PROPERTIES OF BACABA (OENOCARPUS BACABA MART.) OIL
}

\author{
Hugo Maia Fonseca ${ }^{1}$, Camila Oliveira Santos ${ }^{2}$, Luis Paulo Adami Cruz ${ }^{3}$, \\ Valter Arthur ${ }^{4}$, Bárbara Catarina Bastos Freitas ${ }^{5}$, Adriana Régia Marques Souza 6 , \\ Glêndara Aparecida de Souza Martins ${ }^{7 凶}$
}

\author{
1Pharmacy Department, Guaraí Faculty, Santa Catarina Educational Institute \\ Av. JK 2541, 77700-000 Guaraí, Tocantins, Brazil \\ ${ }^{2}$ Chemistry Institute, Federal University of Góias \\ Av. Esperança s/n, 74690-900 Goiânia, Góias, Brazil \\ ${ }^{3}$ Food Engineering Department, Federal University of Tocantins \\ Av. NS 15, Quadra 109 Norte, Plano Diretor Norte, 77001-090 Palmas, Tocantins, Brazil \\ ${ }^{4}$ Department of Irradiation Technology Center-CTR, University of São Paulo, Institute of Nuclear Energy Research-IPEN/USP \\ Av. Lineu Prestes 2242, 05508-000 São Paulo, SP, Brazil \\ ${ }^{5}$ Laboratory of Kinetics and Process Modeling, Graduate Program in Food Science and Technology, Federal University of Tocantins \\ Av. NS 15, Quadra 109 Norte, Plano Diretor Norte, 77001-090 Palmas, Tocantins, Brazil \\ ${ }^{6}$ Agronomy School, Federal University of Góias \\ Av. Esperança s/n, 74690-900 Goiânia, Góias, Brazil \\ ${ }^{7}$ Federal University of Tocantins \\ Av. NS 15, Quadra 109 Norte, ALCNO-14 - Plano Diretor Norte, 77001-090 Palmas, Tocantins, Brazil
}

\begin{abstract}
Background. Bacaba (Oenocarpus bacaba Mart.) has a high yield of oil, with the potential to produce biologically active natural products and can be considered a new "superfruit" with high value added.

Materials and methods. Acid value, peroxide value, refractive index, saponification value, p-anisidine value, relative density, iodine value, total oxidation value, specific extinction coefficients at 232 and $270 \mathrm{~nm}$ $\left(K_{232}\right.$ and $\left.K_{270}\right), \Delta K$, and color were determined.

Results. The most significant changes in the quality values, such as peroxide $\left(26.25 \mathrm{mEq} \cdot \mathrm{kg}^{-1}\right), \mathrm{p}$-anisidine (11.41), acidity (14.66 $\left.\mathrm{mg} \mathrm{KOH} \cdot \mathrm{g}^{-1} \mathrm{oil}\right)$, and total oxidation (63.92) were determined for $15 \mathrm{~min}$ of microwave heating.

Conclusions. The microwave heating promoted the acceleration of oxidative processes showing that, overall, much care should be taken when heating the bacaba oil by microwave to avoid oil degradation.
\end{abstract}

Keywords: Amazon and Cerrado biomes, bacaba oil, microwave heating, oil quality, physicochemical properties 


\section{INTRODUCTION}

The Amazon rainforest has a broad diversity of plant and vegetable species, including native ones not yet explored. The use of this biodiversity has great economic importance for this region (Costa et al., 2017; Torres et al., 2019). One of the most exploited species by regional extractive is the bacaba palm (Oenocarpus bacaba Mart.) that produces fruits called 'bacaba', characterized as edible purple berries.

Bacaba fruits have a nutritional and bioactive potential still little explored. The fruits have a high yield of vegetable oils, with the potential to produce biologically active natural products. Among these, fat-soluble vitamins, carotenoids (provitamin A), tocopherols (provitamin $\mathrm{E}$ and antioxidant), dyes, and flavonoids can be highlighted. A significant group of compounds present in bacaba is anthocyanins, which are plant-derived compounds belonging to the flavonoid's subgroup of phenolic compounds (Costa et al., 2017; Cunha et al., 2019). The fatty acids present in bacaba are considered essential to life and are known as essential unsaturated fatty acids and must be supplied by food. The prominent representatives of essential unsaturated fatty acids in bacaba oil are omega- 9 , omega-6, and omega-3. The oil from bacaba is rich in unsaturated fatty acids, mainly oleic $(3070 \%)$ and palmitic (1030\%), and phenolic compounds, has a lightyellow color, is odorless, does not have a strong flavor and is traditionally only used for cooking (Costa et al., 2017; Cunha et al., 2019; Morais et al., 2019; Nascimento et al., 2019; Torres et al., 2019).

The use of microwave heating at home and in the food industry remains a modern technology. This presents advantages due to its convenience, speed, capacity to transmit heat, and time/energy saving (Bakhshabadi et al., 2017; Hashemi et al., 2017; Hayat et al., 2019). The process of heating by microwaves is almost instantaneous and able to disrupt the cell structure by increasing the internal pressure, releasing bioactive compounds (Chan et al., 2017). Various chemical reactions may occur during microwave heating that determine the oil's quality and safety, and with this, some components may be degraded and others not (Costa et al., 2017; Musa Özcan et al., 2019).

In this context, the objective of this work was to evaluate whether microwave heating has any influence on the physicochemical properties of bacaba oil (Oenocarpus bacaba Mart.) extracted by pressing.

\section{MATERIALS AND METHODS}

\section{Materials}

Bacaba fruits (Oenocarpus bacaba Mart.) were purchased from the local market at Palmas city, Tocantins, Brazil. The fruits were sanitized, packed in polyethylene bags, and stored at $18^{\circ} \mathrm{C}$ till oil extraction and analysis.

\section{Extraction of oil from bacaba pulp}

Oil extraction from the bacaba pulp was carried out at the Laboratory of Materials and Composites at the Federal University of Tocantins. The pulp was extracted manually at room temperature. It was then dried at $105^{\circ} \mathrm{C}$ for $10 \mathrm{~h}$ with air circulation until it reached constant weight. The oil was pressed using a hydraulic press (Nowak Tons, Brazil) at room temperature, where samples of $80 \mathrm{~g}$ of pulp were subjected to a maximum pressure of $147 \mathrm{MPa}$. After pressing, the oil was centrifuged $(3500 \mathrm{rpm} / 6 \mathrm{~min})$ for the separation of suspended material, then packed in amber flasks and stored at $4^{\circ} \mathrm{C}$ till analysis.

\section{Microwave heating}

Heating was performed using a domestic microwave oven (Eletrolux ${ }^{\circledR}$ MEF14) with 700 Watts (to measure the effect of domestic heating on the quality of the bacaba oil), and the maximum temperature reached by the oil was $160^{\circ} \mathrm{C}$. Each sample was placed in petri dishes (45 ml of oil) and exposed to 1, 3, 5, 10, and 15 minutes of heating. The samples were cooled and packed in an amber flask and stored at $4^{\circ} \mathrm{C}$ till analysis.

\section{Oil analysis}

The analyses were carried out at the Laboratory of Fruit Technology - LAFRUTEC and Laboratory of the Food Analysis - LANA, both from the Federal University of Tocantins.

Acid value (AV), peroxide value (PV), refractive index (RI), saponification value (SV), p-anisidine value $(\mathrm{AnV})$ and the relative density $(\mathrm{RD})$ were all determined according to the proposed method by AOCS (2004). The iodine value (IV) was determined using the Wijs Method according to the $\mathrm{Cd} 1 \mathrm{~b}-87$ methods of 
AOCS (2004), using chloroform as a solvent. The Total Oxidation Value (TOTOX) was calculated with the use of Equation 1, as proposed by Silva et al. (1999).

$$
\mathrm{TOTOX}=2(\mathrm{PV})+\mathrm{AnV}
$$

The specific extinction coefficients at 232 and 270 $\mathrm{nm}\left(K_{232}\right.$ and $\left.K_{270}\right)$ and $\Delta K$ were determined following Regulation $\mathrm{N}^{\mathrm{0}}$ 2568/91 (Characteristics..., 1991).

The heated oil color was measured instrumentally with a colorimeter (Chroma Meter CR-400) programmed for the model CIE $\left(L^{*}, a^{*}\right.$, and $\left.b^{*}\right)$, using a polystyrene cuvette with $45 \times 12.5 \times 12.5 \mathrm{~mm}$ (height $\times$ width $\times$ depth) and an optical path of $10 \mathrm{~mm}$ and $1.25 \mathrm{~mm}$ thick. The results were expressed as $L^{*}$ (lightness), $a^{*}$ (red to green content), and $b^{*}$ (yellow to blue content), as the methodology Cc13e-92 from AOCS (2004). From the data obtained, the saturation parameter $(C)$ and hue angle $\left(h^{\circ}\right)$ were calculated (Precise color..., 1998).

\section{Statistical analysis}

Statistical analysis was performed using the ASSISTAT ${ }^{\circledR}$ program. A completely randomized design
(DIC) was used, with an analysis of variance, where the samples were analyzed in triplicates. Their means were subjected to the Tukey test at the level of $1 \%$.

\section{RESULTS AND DISCUSSION}

The bacaba pulp used for the oil extraction had its initial moisture reduced from $38.37 \pm 3.65 \%$ to $10 \pm 1.2 \%$, and the extraction by a hydraulic press reached a high oil yield of $19.34 \%\left(\mathrm{w} \cdot \mathrm{w}^{-1}\right)$. The extraction yield of the bacaba oil was above the yield obtained by passion fruit seed $(16.02 \%)$ and pomegranate seed $(12 \%)$ (Domingues et al., 2014; Silva et al., 2014). However, when compared to oilseeds, the extraction yield of the bacaba oil was lower than that determined by Barroso et al. (2014) for brown (36.5\%) and golden (35.4\%) linseeds. It was possible to observe the negative effects concerning the acid value caused by microwave heating in bacaba oil (Table 1). The highest acid value (14.66 $\mathrm{mg} \mathrm{KOH} \cdot \mathrm{g}^{-1}$ oil - Table 1) for the bacaba oil was found for 15 min of heating. Hydrolysis can explain this behavior in vegetable oils and the increase of total acidity due to the decomposition of some

Table 1. Effects of microwave heating on acid value (AV), iodine value (IV), refractive index (RI), saponification value $(\mathrm{SV})$, relative density $(\mathrm{RD})$, peroxide value $(\mathrm{PV})$, p-anisidine value $(\mathrm{AnV})$, total oxidation value (TOTOX), specific extinction coefficients at 232 and $270 \mathrm{~nm}\left(K_{232}\right.$ and $\left.K_{270}\right)$ and $\Delta K$ of bacaba oil at different exposures times

\begin{tabular}{|c|c|c|c|c|c|c|c|c|c|c|c|}
\hline $\begin{array}{l}\text { Time } \\
\min \end{array}$ & $\begin{array}{c}\mathrm{AV}^{*} \\
\mathrm{mg} \mathrm{KOH} \cdot \mathrm{g}^{-1} \text { oil }\end{array}$ & $\begin{array}{c}\mathrm{IV}^{\mathrm{ns}} \\
\mathrm{mg} \mathrm{I}_{2} \cdot \mathrm{g}^{-1}\end{array}$ & $\mathrm{RI}^{*}$ & $\begin{array}{c}\mathrm{SV}^{*} \\
\mathrm{mg} \mathrm{KOH} \cdot \mathrm{g}^{-1} \text { oil }\end{array}$ & $\begin{array}{c}\mathrm{RD}^{*} \\
\mathrm{~g} \cdot \mathrm{mL}^{-1}\end{array}$ & $\begin{array}{c}\mathrm{PV}^{*} \\
\mathrm{mEq} \cdot \mathrm{kg}^{-1}\end{array}$ & $\mathrm{AnV}^{*}$ & TOTOX* & $K_{232}{ }^{*}$ & $K_{270}{ }^{*}$ & $\Delta K^{*}$ \\
\hline 0 & $\begin{aligned} & 1.65^{\mathrm{e}} \\
\pm & 0.02\end{aligned}$ & $\begin{array}{l}51.35^{\mathrm{a}} \\
\pm 1.53\end{array}$ & $\begin{array}{r}1.46^{\mathrm{a}} \\
< \\
<0.01\end{array}$ & $\begin{array}{c}225.56^{\mathrm{a}} \\
\pm 0.29\end{array}$ & $\begin{aligned} & 0.91^{\mathrm{a}} \\
< & 0.01\end{aligned}$ & $\begin{array}{r}6.79^{\mathrm{e}} \\
\pm 0.86\end{array}$ & $\begin{aligned} & 1.34^{\mathrm{d}} \\
\pm & 0.71\end{aligned}$ & $14.92^{\mathrm{e}}$ & $\begin{array}{l}17.31^{\mathrm{d}} \\
\pm 0.18\end{array}$ & $\begin{aligned} & 2.92^{\mathrm{d}} \\
\pm & 0.03\end{aligned}$ & $\begin{array}{r}3.00^{\mathrm{d}} \\
\pm 0.13\end{array}$ \\
\hline 1 & $\begin{array}{r}9.26^{\mathrm{c}} \\
\pm 0.07\end{array}$ & $\begin{array}{l}50.76^{\mathrm{a}} \\
\pm 0.75\end{array}$ & $\begin{array}{r}1.47^{\mathrm{a}} \\
<0.01\end{array}$ & $\begin{array}{c}224.59^{\mathrm{a}} \\
\pm 2.18\end{array}$ & $\begin{array}{c}0.89^{\mathrm{ab}} \\
\pm 0.01\end{array}$ & $\begin{array}{l}9.68^{\mathrm{de}} \\
\pm 2.42\end{array}$ & $\begin{aligned} & 1.40^{\mathrm{d}} \\
\pm & 0.10\end{aligned}$ & $20.75^{\text {de }}$ & $\begin{array}{l}16.06^{\mathrm{e}} \\
\pm 0.23\end{array}$ & $\begin{array}{c}2.72^{\mathrm{e}} \\
\pm 0.13\end{array}$ & $\begin{array}{r}2.63^{\mathrm{d}} \\
\pm 0.17\end{array}$ \\
\hline 3 & $\begin{aligned} & 9.31^{\mathrm{c}} \\
\pm & 0.24\end{aligned}$ & $\begin{array}{l}51.56^{\mathrm{a}} \\
\pm 1.39\end{array}$ & $\begin{array}{r}1.47^{\mathrm{a}} \\
<0.01\end{array}$ & $\begin{array}{c}223.49^{\mathrm{ab}} \\
\pm 1.20\end{array}$ & $\begin{array}{r}0.91^{\mathrm{a}} \\
<0.01\end{array}$ & $\begin{array}{l}12.06^{\mathrm{d}} \\
\pm 0.02\end{array}$ & $\begin{array}{l}2.84^{\text {cd }} \\
\pm 0.52\end{array}$ & $26.97^{\mathrm{d}}$ & $\begin{array}{l}18.06^{\mathrm{c}} \\
\pm 0.09\end{array}$ & $\begin{array}{c}3.10^{\mathrm{c}} \\
\pm 0.09\end{array}$ & $\begin{aligned} & 3.19^{\mathrm{d}} \\
\pm & 0.03\end{aligned}$ \\
\hline 5 & $\begin{aligned} & 8.37^{\mathrm{d}} \\
\pm & 0.10\end{aligned}$ & $\begin{array}{l}50.77^{\mathrm{a}} \\
\pm 0.58\end{array}$ & $\begin{array}{r}1.47^{\mathrm{a}} \\
<0.01\end{array}$ & $\begin{array}{c}220.09^{\mathrm{b}} \\
\pm 2.34\end{array}$ & $\begin{array}{r}0.88^{\mathrm{b}} \\
\pm 0.01\end{array}$ & $\begin{array}{l}17.69^{\mathrm{c}} \\
\pm 1.45\end{array}$ & $\begin{aligned} & 4.43^{\mathrm{c}} \\
\pm & 0.14\end{aligned}$ & $39.81^{\mathrm{c}}$ & $\begin{array}{l}18.54^{\mathrm{bc}} \\
\pm 0.15\end{array}$ & $\begin{array}{l}7.72^{\mathrm{bc}} \\
\pm 0.14\end{array}$ & $\begin{array}{r}7.42^{\mathrm{c}} \\
\pm 0.16\end{array}$ \\
\hline 10 & $\begin{array}{l}10.47^{\mathrm{b}} \\
\pm 0.17\end{array}$ & $\begin{array}{l}50.25^{\mathrm{a}} \\
\pm 0.36\end{array}$ & $\begin{array}{r}1.45^{\mathrm{b}} \\
\pm 0.01\end{array}$ & $\begin{array}{c}210.26^{\mathrm{c}} \\
\pm 2.19\end{array}$ & $\begin{array}{r}0.86^{\mathrm{c}} \\
\pm 0.01\end{array}$ & $\begin{array}{l}21.53^{\mathrm{b}} \\
\pm 0.22\end{array}$ & $\begin{aligned} & 7.30^{\mathrm{b}} \\
\pm & 0.63\end{aligned}$ & $50.36^{\mathrm{b}}$ & $\begin{array}{l}19.11^{\mathrm{b}} \\
\pm 0.20\end{array}$ & $\begin{array}{l}12.52^{\mathrm{b}} \\
\pm 0.43\end{array}$ & $\begin{array}{l}11.75^{\mathrm{b}} \\
\pm 0.53\end{array}$ \\
\hline 15 & $\begin{array}{l}14.66^{\mathrm{a}} \\
\pm 0.11\end{array}$ & $\begin{array}{l}49.89^{\mathrm{a}} \\
\pm 0.66\end{array}$ & $\begin{array}{r}1.44^{\mathrm{c}} \\
<0.01\end{array}$ & $\begin{array}{c}201.45^{\mathrm{d}} \\
\pm 0.55\end{array}$ & $\begin{array}{r}0.84^{\mathrm{d}} \\
<0.01\end{array}$ & $\begin{array}{l}26.25^{\mathrm{a}} \\
\pm 0.13\end{array}$ & $\begin{array}{l}11.41^{\mathrm{a}} \\
\pm 0.95\end{array}$ & $63.92^{\mathrm{a}}$ & $\begin{array}{l}22.39^{\mathrm{a}} \\
\pm 0.49\end{array}$ & $\begin{array}{l}15.13^{\mathrm{a}} \\
\pm 0.18\end{array}$ & $\begin{array}{l}14.26^{\mathrm{a}} \\
\pm 0.59\end{array}$ \\
\hline
\end{tabular}

"Significant at the level of $1 \%$ probability $(p=0.01)$, by the $F$ test.

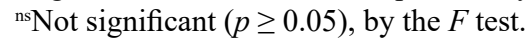

Results expressed as mean \pm deviation of analyses in triplicate.

Different letters in the same column indicate a significant difference by the Tukey test. 
phospholipids and triacylglycerols to glycerol and free fatty acids promoted by microwave heating (Musa Özcan et al., 2019). Chiavaro et al. (2010) observed the same tendency of the acid value to increase with an increase in the time of exposure to microwaves for vegetable oils from peanut, sunflower, and canola.

Microwave heating did not significantly affect the iodine index of the samples (Table 1). Iodine value indicates the degree of unsaturation of oil (Fathi-Achachlouei et al., 2019) and is often used as a rough criterion of stability during heating (Anjum et al., 2006). So, according to the results obtained (IV - Table 1), bacaba oil tends to have fewer mono or polyunsaturated compounds and a higher resistance to heat.

The Refractive index is a parameter that shows the purification and quality of oil. This parameter increases with an enhancement in the chain length and the unsaturation of fatty acid contents (Bakhshabadi et al., 2017; Fathi-Achachlouei et al., 2019; Godswill et al., 2018). Short exposure times to microwave heating (up to $5 \mathrm{~min}$ ) did not change the refractive index of bacaba oil, but it can be seen that there is a downward trend in this rate with increasing exposure time (10 and 15 min - Table 1). This behavior may be a result of the higher temperatures obtained with longer exposure times since the temperature is considered a factor of influence on the refractive index (Bakhshabadi et al., 2017). These results demonstrate a possible change in the unsaturation or size of the hydrocarbon chain, showing a direct correlation with the results obtained for the iodine index (Table 1), which is also a parameter that indicates the degree of unsaturation of oil (Fathi-Achachlouei et al., 2019).

It was found that there was no significant change in the saponification index values up to $3 \mathrm{~min}$ of exposure. A progressive decrease to the minimum amount of $201.45 \mathrm{mg} \mathrm{KOH} \cdot \mathrm{g}^{-1}$ oil $(10.7 \%$ concerning the control sample) obtained for $15 \mathrm{~min}$ of exposure was observed (SV - Table 1). Musa Özcan et al. (2019) determined that the saponification values of chia oils heated in a microwave change between $215.03 \mathrm{mg} \mathrm{KOH} / \mathrm{g}(900 \mathrm{~W}$ ) and $218.03 \mathrm{mg} \mathrm{KOH} / \mathrm{g}(180 \mathrm{~W})$. The results obtained in this work for bacaba oil (SV - Table 1, for 5,10 , and $15 \mathrm{~min}$ ), as well as results obtained for chia (Musa Özcan et al., 2019), indicate that an increased time of exposure or even an increase in the potency of microwave radiation can promote the degradation of mono or polyunsaturated compounds. As a determination of the saponification value (SV) of oils is crucial for estimating their quality (Endo et al., 2005), exposure to microwave radiation for longer times or at higher powers can affect the quality of the oil.

The times 0,1 , and 3 min were statistically equal for the relative density measurements; however, from 5 minutes, a significant change was observed in the oil density (RD - Table 1). The results suggest a break in carbon chains that can interfere with density values, already induced by the reduction of saponification and refraction indexes, as the variation of density is directly proportional to the chemical reactions that occur in the oil (Albi et al., 1997; Musa Özcan et al., 2019).

Microwave heating triggered a gradual and systematic increase $\left(r^{2}=0.9539\right)$ in the peroxide value in bacaba oil (PV - Table 1). The maximum value obtained for the peroxide value was $26.25 \mathrm{mEq} \cdot \mathrm{kg}^{-1}$ for the time of $15 \mathrm{~min}$. However, an increase in the exposure time from $5 \mathrm{~min}$ is already sufficient for the formation of organic peroxides that exceed the limit established by Brazilian legislation ( $\mathrm{RDC}^{\circ}{ }^{\circ} 270 / 2005-$ Brazil, 2005), which stipulates a maximum IP value of $15 \mathrm{mEq} \cdot \mathrm{kg}^{-1}$.

Malheiro et al. (2009) observed that microwave heating changed the quality of olive oil obtained from 3 cultivars. The authors also observed that in only one of the cultivars, it was possible to define a positive correlation between the increase in exposure time and the increase in the peroxide index, the same tendency as that determined in this work for the bacaba oil. The authors suggest that the other cultivars' oxidation possibly reached the maximum value and then started to reduce to secondary compounds, demonstrating the instability of olive oil under microwave heating.

Microwave radiation can accelerate the deterioration of bacaba oil once longer times of microwave heating causes an increase in the peroxide value and the p-anisidine values (PV and AnV - Table 1). An increase in microwave power or exposure to radiation can result in an enhancement in oxidation. When the peroxide concentration reaches higher levels, different alterations are generated in the available fat contents' physicochemical and organoleptic properties, resulting in unpleasant tastes and smells for the consumer (Bakhshabadi et al., 2017). These alterations can occur in bacaba oil exposed to microwave heating since the 
peroxide value increases with an increase in heating time (PV - Table 1).

The $\mathrm{p}$-anisidine value $(\mathrm{AnV})$ refers to the formation of more stable secondary products of lipid oxidation. This relates the susceptibility to the oxidation of fatty acids differently from that analyzed by the peroxide value (Casal et al., 2010). AnV values below 10 indicate low concentrations of degradation compounds (Casal et al., 2010; Silva et al., 1999). Values above those recommended for this index were found for bacaba oil only when the samples were subjected to microwave heating for $15 \min (\mathrm{AnV}=11.49$ - Table 1). Therefore, this extended time of exposure to microwave radiation can be considered the only treatment that produced secondary degradation compounds. With the results obtained for the AnV (Table 1), it was possible to establish a positive correlation between the time of exposure to the microwave and the increase in this index $\left(r^{2}=0.9935\right)$.

Chiavaro et al. (2010) analyzed microwave heating on peanut, sunflower, and canola oils at different times. The oils obtained showed initial $\mathrm{AnV}$ values (0 min) of 2.70, 3.15, and 1.90 for peanut, sunflower, and canola, respectively. For a heating time of $6 \mathrm{~min}$, all samples showed $\mathrm{AnV}>10$, with a positive correlation of $r^{2}=0.8266$ (canola), $r^{2}=0.9248$ (sunflower), and $r^{2}=$ 0.8565 (peanut). These correlations between exposure time and index variation are similar to the results obtained for bacaba oil. It can also be observed that the bacaba oil is more resistant to heating by microwave and more stable to the formation of secondary oxidation compounds concerning the oils studied by Chiavaro et al. (2010). This highest resistance can be explained since $\mathrm{AnV}$ values more significant than ten were determined only after 15 min of microwave heating (Table 1).

Wai et al. (2009) and Silva et al. (1999) demonstrated that it is possible to calculate the total oxidation value (TOTOX) from the parameters of PV and AnV; in addition, it should be considered that oil is stable when it has a TOTOX value up to 10 . The control sample of bacaba oil ( $0 \mathrm{~min}$ ) had the lowest TOTOX, but all samples had TOTOX $>10$ (Table 1). According to Silva et al. (1999), the calculation of TOTOX from the parameters $\mathrm{PV}$ and $\mathrm{AnV}$ make it possible to establish the correlation between the level of peroxides, which represents the potential for degradation of the organoleptic quality, and aldehydes. Thus, the results obtained in this study allow us to state that the longer the exposure time to microwave heating, the greater the degradation in bacaba oil. This behavior is also confirmed because the correlation between the exposure time with the TOTOX was positive $\left(r^{2}=0.9725\right)$, ensuring that the quality of bacaba oil is significantly influenced by the time of exposure to microwaves.

The $K_{232}$ correlates with the formation of conjugated dienes of polyunsaturated fatty acids. At the same time, the $K_{270}$ values are indicative of the presence of primary and secondary oxidation products, including conjugated trienes and carbonyl compounds. The maximum amount allowed for $K_{270}$ is 0.90 for common vegetable oils, and the $K_{232}$ values are required to be lower than 2.5 or even not evaluated. The $\Delta K$ is also a measure of lipid secondary oxidation, with maximum amounts of 0.15 for oil blends (Casal et al., 2010; Gharby et al., 2016; Pannico et al., 2015; Paraskevopoulou et al., 2007). There is a significant rise in $K_{232}$ and $K_{270}$ values with an increase in microwave heating time, as can be observed in Table 1. The highest values of the $K_{232}$ and $K_{270}$ coefficients obtained for bacaba oil were 22.39 and 15.13 , respectively, both in $15 \mathrm{~min}$. As changes in the ultraviolet spectrum have been used as a relative measure of oxidation (Gharby et al., 2016) and $K_{232}$ values larger than 2.5 are deemed rancid (Pannico et al., 2015) it can be assumed that microwave heating proves detrimental to the quality of bacaba oil.

The control sample ( $0 \mathrm{~min}$ ) showed $K_{270}$ to be greater than 0.90 and $K_{232}$ to be greater than 2.5 , suggesting that it already had residues of primary and secondary oxidation compounds before the microwave treatment. This characteristic of the control sample may be the result of the formation of conjugated dienes and trienes proportional to the uptake of oxygen and the formation of peroxides during the initial stages of oxidation (Gharby et al., 2016) which ends up directly affecting increased absorption at $232 \mathrm{~nm}$ and $270 \mathrm{~nm}$ for samples exposed to microwave heating. $\Delta K$ values for all samples were above the recommended value of 0.15 (Table 1). As the control sample $(0 \mathrm{~min})$ and those exposed to heating for 1 and 3 min showed no statistical difference for $\Delta K$, it is possible to observe that exposure to microwaves tends to raise the formation of organic peroxides and secondary degradation compounds with an increase in exposure time. 
Fonseca, H. M., Oliveira Santos, C., Adami Cruz, L. P., Arthur, V., Bastos Freitas, B. C., Marques Souza, A. R., de Souza Martins, G. A. (2021). The effects of microwave application on the physicochemical properties of bacaba (Oenocarpus bacaba Mart.) oil. Acta Sci. Pol. Technol. Aliment., 20(2), 189-196. http://dx.doi.org/10.17306/J.AFS.2021.0893

Table 2. Effect of microwave heating on color properties of bacaba oil at different exposures times

\begin{tabular}{|c|c|c|c|c|c|}
\hline \multirow{2}{*}{$\begin{array}{l}\text { Time } \\
\text { min }\end{array}$} & \multicolumn{5}{|c|}{ Parameters } \\
\hline & $L^{*}$ & $a^{*, *}$ & $b^{*, *}$ & $C^{*}$ & $h^{\mathrm{o}^{*}}$ \\
\hline 0 & $19.42^{\mathrm{a}} \pm 0.06$ & $1.89^{\mathrm{a}} \pm 0.08$ & $3.33^{\mathrm{a}} \pm 0.03$ & $3.83^{\mathrm{a}} \pm 0.06$ & $60.43^{\mathrm{b}} \pm 0.87$ \\
\hline 1 & $19.45^{\mathrm{a}} \pm 0.30$ & $1.43^{\mathrm{b}} \pm 0.06$ & $3.44^{\mathrm{a}} \pm 0.15$ & $3.72^{\mathrm{a}} \pm 0.15$ & $67.47^{\mathrm{a}} \pm 0.90$ \\
\hline 3 & $19.36^{\mathrm{a}} \pm 0.23$ & $1.46^{\mathrm{b}} \pm 0.05$ & $3.51^{\mathrm{a}} \pm 0.17$ & $3.80^{\mathrm{a}} \pm 0.18$ & $67.33^{\mathrm{a}} \pm 0.30$ \\
\hline 5 & $18.58^{\mathrm{b}} \pm 0.09$ & $1.40^{\mathrm{b}} \pm 0.02$ & $2.37^{\mathrm{b}} \pm 0.07$ & $2.75^{\mathrm{b}} \pm 0.05$ & $59.41^{\mathrm{b}} \pm 1.10$ \\
\hline 10 & $16.43^{\mathrm{c}} \pm 0.09$ & $1.35^{\mathrm{b}} \pm 0.03$ & $2.27^{\mathrm{b}} \pm 0.04$ & $2.64^{\mathrm{b}} \pm 0.04$ & $59.19^{\mathrm{b}} \pm 0.62$ \\
\hline 15 & $14.34^{\mathrm{d}} \pm 0.11$ & $1.18^{\mathrm{c}} \pm 0.02$ & $1.94^{c} \pm 0.06$ & $2.27^{\mathfrak{c}} \pm 0.06$ & $58.68^{\mathrm{b}} \pm 0.59$ \\
\hline
\end{tabular}

*Significant at the level of $1 \%$ probability $(p=0.01)$, by the $F$ test.

Results expressed as mean \pm deviation of analyses in triplicate.

Different letters in the same column indicate a significant difference by the Tukey test.

Microwave heating can alter the luminosity of bacaba oil, as significant changes to the parameter $L^{*}$ were observed from the exposure time of 5 minutes, with the most considerable interference determined at 15 min (Table 1). It was observed that the microwaves changed the parameters $a^{*}, b^{*}$, and $C$ discretely. Although not perceptible to the human eye, the samples submitted to heating for 1 and $3 \mathrm{~min}$ showed higher $h^{\circ}$ values (Table 1), approaching a more yellowish color. The hue angle at $90^{\circ}$ represents pure yellow (Ramallo and Mascheroni, 2012). The angle values $\left(h^{\circ}\right)$ determined for samples heated for $0,5,10$, and $15 \mathrm{~min}$ (Table 1) indicate a tendency to have a more reddish color since the proximity of the hue angle with $0^{\circ}$ represents pure red (Ramallo and Mascheroni, 2012). The longer the heating time, the greater the intensification of the color, as browning substances tend to be formed. The formation of browning substances can be related to the hydrolyzation of triacylglycerols by microwaves to produce free fatty acids. An increase in microwave heating time can be accompanied by an increase in the browning substances and degradation of phospholipids, which may be attributed to the increase in polar lipids. Phospholipids were reported to cause browning of the oil during heating. Besides that, an increase in browning substances may be attributable to the increase in contents of other lipids, such as glyceroglycolipids, in the oil (Anjum et al., 2006).

As the food color is arguably one of the most critical determinants of acceptability for many food products (Giusti et al., 2017), microwave heating for short periods, up to $15 \mathrm{~min}$, can be used to prevent visible changes of the product to the human eye. The tendency presented in this study shows that the longer the heating time the greater the color change, as well as the degradation of bacaba oil (Table 1).

\section{CONCLUSION}

The results of this work show that the time of exposure to microwave heating has a significant effect on the physicochemical parameters of bacaba oil. Microwave heating did not change the iodine value of bacaba oil. Refractive index, saponification value and relative density partially decreased together with an increase in exposure time. The highest values of acidity (14.66 $\mathrm{mg} \mathrm{KOH} \cdot \mathrm{g}^{-1}$ oil), peroxides $\left(26.25 \mathrm{mEq} \cdot \mathrm{kg}^{-1}\right)$, p-anisidine (11.41), total oxidation (63.92), $K_{232}(22.39), K_{270}$ (15.13) and $\Delta K(14.26)$ were determined for $15 \mathrm{~min}$ of heating. Longer times of microwave heating also promote the greatest color changes. Overall, it can be concluded that times longer than 15 minutes of exposure to microwave heating at 700 watts can deteriorate the quality by promoting the oxidation of bacaba oil.

\section{ACKNOWLEDGMENTS}

The authors thank the Coordination for the Improvement of Higher Education Personnel (CAPES, Brazil), for their financial support offered through scholarships, 
and the National Council for Scientific and Technological Development (CNPq, Brazil).

\section{REFERENCES}

Albi, T., Lanzón, A., Guinda, A., Pérez-Camino, M. C., León, M. (1997). Microwave and conventional heating effects on some chemical parameters of edible fats. J. Agric. Food Chem., 45, 3000-3003. https://doi. org/10.1021/jf970168c

Anjum, F., Anwar, F., Jamil, A., Iqbal, M. (2006). Microwave roasting effects on the physico-chemical composition and oxidative stability of sunflower seed oil. J. Am. Oil Chem. Soc., 83, 777-784. https://doi.org/10.1007/ s11746-006-5014-1

AOCS (2004). Official methods and recommended practices of the American Oil Chemists Society (5th ed.). Champaign: AOCS Press.

Bakhshabadi, H., Mirzaei, H., Ghodsvali, A., Jafari, S. M., Ziaiifar, A. M., Farzaneh, V. (2017). The effect of microwave pretreatment on some physico-chemical properties and bioactivity of Black cumin seeds' oil. Ind. Crops Prod., 97, 1-9. https://doi.org/10.1016/j.indcrop.2016.12.005

Barroso, A. K. M., Torres, A. G., Castelo-Branco, V. N., Ferreira, A., Finotelli, P. V., Freitas, S. P., Rocha-Leão, M. H. M. (2014). Linhaça marrom e dourada: propriedades químicas e funcionais das sementes e dos óleos prensados a frio. Ciência Rural 44(1), 181-187.

BRAZIL (2005). Resolução da Diretoria Colegiada no. 270 de 22/09/2005. Agência Nacional de Vigilância Sanitária $1,2-7$.

Casal, S., Malheiro, R., Sendas, A., Oliveira, B. P. P., Pereira, J. A. (2010). Olive oil stability under deep-frying conditions. Food Chem. Toxicol., 48, 2972-2979. https://doi. org/10.1016/j.fct.2010.07.036

Chan, C. H., See, T. Y., Yusoff, R., Ngoh, G. C., Kow, K. W. (2017). Extraction of bioactives from Orthosiphon stamineus using microwave and ultrasound-assisted techniques: Process optimization and scale up. Food Chem., 221, 1382-1387. https://doi.org/10.1016/j.foodchem.2016.11.016

Chiavaro, E., Rodriguez-Estrada, M. T., Vittadini, E., Pellegrini, N. (2010). Microwave heating of different vegetable oils: Relation between chemical and thermal parameters. LWT - Food Sci. Technol., 43, 1104-1112. https://doi.org/10.1016/j.lwt.2010.02.016

Costa, W. A., Oliveira, M. S., Silva, M. P., Cunha, V. M. B., Pinto, R. H. H., Bezerra, F. W. F., Junior, R. N. C. (2017).
Açaí (Euterpe oleracea) and bacaba (Oenocarpus ba$c a b a)$ as functional food. In: V. Waisundara, N. Shiomi (Eds.), Superfood and functional food - An overview of their processing and utilization. BoD - Books on Demand. https://doi.org/10.5772/65881

Characteristics of olive oil and olive residue oil and on the relevant methods of analysis (1991). Commission Regulation (EEC) No. 2568/91. OJ L 248, 5.9.1991, p. 1.

Cunha, V. M. B., Silva, M. P., Sousa, S. H. B., Bezerra, P. N., Menezes, E. G. O., Silva, N. J. N., ..., Carvalho Junior, R. N. (2019). Bacaba-de-leque (Oenocarpus distichus Mart.) oil extraction using supercritical $\mathrm{CO}_{2}$ and bioactive compounds determination in the residual pulp. J. Supercrit. Fluids, 144, 81-90. https://doi.org/10.1016/j. supflu.2018.10.010

Domingues, S. J., Silva, I. M., Andrade, E. T., Ferreira, F. (2014). Extração do óleo, produção e caracterização de propriedades físicas do biodiesel de sementes de maracujá - Passiflora edulis. Engevista, 16(1), 1-7.

Endo, Y., Tagiri-Endo, M., Kimura, K. (2005). Rapid determination of iodine value and saponification value of fish oils by near-infrared spectroscopy. J. Food Sci., 70. https://doi.org/10.1111/j.1365-2621.2005.tb07072.x

Fathi-Achachlouei, B., Azadmard-Damirchi, S., Zahedi, Y., Shaddel, R. (2019). Microwave pretreatment as a promising strategy for increment of nutraceutical content and extraction yield of oil from milk thistle seed. Ind. Crops Prod., 128, 527-533. https://doi.org/10.1016/j. indcrop.2018.11.034

Gharby, S., Harhar, H., Matthäus, B., Bouzoubaa, Z., Charrouf, Z. (2016). The chemical parameters and oxidative resistance to heat treatment of refined and extra virgin Moroccan Picholine olive oil. J. Taibah Univ. Sci., 10, 100-106. https://doi.org/10.1016/j.jtusci.2015.05.004

Giusti, M. M., Wrolstad, R. E., Smith, D. E. (2017). CIE color specifications calculated from reflectance or transmittance spectra. In: S. S. Nielsen (Ed.), Food analysis laboratory manual (3rd ed.). Springer.

Godswill, A. C., Amagwula, I. O., Victory, I. S., Gonzaga, A. I., State, I. (2018). Effects of repeated deep frying on refractive index and peroxide value of selected vegetable oils. Int. J. Adv. Acad. Res. (IJAAR), 4, 106-119.

Hashemi, S. M. B., Mousavi Khaneghah, A., Koubaa, M., Lopez-Cervantes, J., Yousefabad, S. H. A., Hosseini, S. F., ..., Asadifard, S. (2017). Novel edible oil sources: Microwave heating and chemical properties. Food Res. Int. 92, 147-153. https://doi.org/10.1016/j. foodres.2016.11.033

Hayat, K., Abbas, S., Hussain, S., Shahzad, S. A., Tahir, M. U. (2019). Effect of microwave and conventional 
oven heating on phenolic constituents, fatty acids, minerals and antioxidant potential of fennel seed. Ind. Crops Prod., 140, 111610. https://doi.org/10.1016/j.indcrop.2019.111610

Malheiro, R., Oliveira, I., Vilas-Boas, M., Falcão, S., Bento, A., Pereira, J. A. (2009). Effect of microwave heating with different exposure times on physical and chemical parameters of olive oil. Food Chem. Toxicol., 47, 92-97. https://doi.org/10.1016/j.fct.2008.10.014

Precise color communication: color control from feeling to instrumentation (1998). Konica Minolta. https://www. konicaminolta.com/instruments/knowledge/color/pdf/ color_communication.pdf

Morais, M. F. de, Santos, J. R. O., Santos, M. P., Santos, D. C., Costa, T. N., Lima, J. B. (2019). Modeling and thermodynamic properties of 'bacaba' pulp drying. Rev. Bras. Eng. Agríc. Ambient., 23, 9, 702-708.

Musa Özcan, M., Al-Juhaimi, F. Y., Mohamed Ahmed, I. A., Osman, M. A., Gassem, M. A. (2019). Effect of different microwave power setting on quality of chia seed oil obtained in a cold press. Food Chem., 278, 190-196. https://doi.org/10.1016/j.foodchem.2018.11.048

Nascimento, A., Andrade, E. L., Santana, E. B., Paixão Ribeiro, N. F., Costa, C. M. L., Faria, L. J. G. (2019). Bacaba powder produced in spouted bed: An alternative source of bioactive compounds and energy food product. Braz. J. Food Technol., 22, 1-15. https://doi. org/10.1590/1981-6723.22918

Pannico, A., Schouten, R. E., Basile, B., Romano, R., Woltering, E. J., Cirillo, C. (2015). Non-destructive detection of flawed hazelnut kernels and lipid oxidation assessment using NIR spectroscopy. J. Food Eng., 160, 42-48. https://doi.org/10.1016/j.jfoodeng.2015.03.015

Paraskevopoulou, D., Boskou, D., Paraskevopoulou, A. (2007). Oxidative stability of olive oil-lemon juice salad dressings stabilized with polysaccharides. Food Chem., 101, 1197-1204. https://doi.org/10.1016/j.foodchem.2006.03.022

Ramallo, L. A., Mascheroni, R. H. (2012). Quality evaluation of pineapple fruit during drying process. Food Bioprod. Proc., 90(2), 275-283. https://doi.org/10.1016/j. fbp.2011.06.001

Silva, N. K., Ribeiro, L. O., Nogueira, R. I., Freitas, S. P. (2014). Efeito do método de extração na capacidade antioxidante dos óleos de semente de romã. Revista Magistra, 25 .

Silva, F. A. M., Borges, M. F. M., Ferreira, M. A. (1999). Métodos para avaliação do grau de oxidação lipídica e da capacidade antioxidante. Quimica Nova, 22, 94-103. https://doi.org/10.1590/s0100-40421999000100016

Torres, M. de P. R., Esprendor, R. V. de F., Bonaldo, S. M., Ribeiro, E. B., Valladã, D. M. de S. (2019). Development, characterization and stability of microemulsionated formulations of bacaba, Oenocarpus bacaba oil. Acta Amaz., 49, 246-255. https://doi.org/10.1590/18094392201802702

Wai, W. T., Saad, B., Lim, B. P. (2009). Determination of TOTOX value in palm oleins using a FI-potentiometric analyzer. Food Chem., 113, 285-290. https://doi. org/10.1016/j.foodchem.2008.06.082 